\title{
26. LEAD ISOTOPE STUDIES OF BASALTS FROM IPOD LEG 49
}

\author{
James M. Mattinson, Department of Geological Sciences, University of California, Santa Barbara, California
}

\begin{abstract}
Basalts from the Reykjanes Ridge (RER) transect (Holes 407, 408, 409) have $\mathrm{Pb}$ isotopic compositions similar to those of basalts dredged from the northern RER and collected from Iceland. Hole 409 basalts, the youngest (about $2.2 \mathrm{~m} . \mathrm{y}$. old) and closest to the RER, are a good match in terms of their $\mathrm{Pb}^{206} / \mathrm{Pb}^{204}$ and $\mathrm{Pb}^{208} / \mathrm{Pb}^{204}$ ratios for basalts dredged from the RER nearby. The Hole 409 basalts also are isotopically quite homogeneous. The isotopic compositions of five out of six samples, spanning almost the entire 239-meter igneous section penetrated at this site, are essentially identical. Other sites show small isotopic variations with depth, however. Basalts from Holes 408 and 407 (upper volcanic section) have $\mathrm{Pb}$ isotopic compositions equal to, or slightly more radiogenic than those for Hole 409, but still in the range of northern RER and Icelandic basalts. This suggests that the Iceland "anomaly" was as developed 20, and possibly $28 \mathrm{~m} . \mathrm{y}$. ago, as it is today.

Basalts from Holes 410 and $410 \mathrm{~A}$ contain very radiogenic $\mathrm{Pb}$-in the range of $\mathrm{Pb}$ from oceanic-island volcanic rocks. The Hole 410/410A basalts evidently have been derived from a relatively undepleted, off-axis mantle source that may reflect a major mantle differentiation event about 1.8 b.y. ago. A mixture of Hole 410/410A material and "normal" MAR material could produce $\mathrm{Pb}$-isotopic compositions identical to those measured at Sites 407, 408, and 409.

Data from FAMOUS area Holes 411, 412A, and 413 confirm earlier indications that the FAMOUS area basalts are isotopically heterogeneous. The data do not fit a simple two-component mixing model, but require a third end-member. Fracture zone B in the FAMOUS area has possibly influenced the isotopic compositions of basalts erupted adjacent to it.
\end{abstract}

\section{INTRODUCTION}

This chapter deals with the isotopic composition of lead in Leg 49 basalts. The main objectives of the lead-isotope study are: (1) to document the evolution of the Icelandic geochemical anomaly with time, (2) to study possible $\mathrm{Pb}$-isotopic variations in Layer 2 of the oceanic crust with depth at a single site, and (3) to measure the isotopic compositions of $\mathrm{Pb}$ from basalts in the FAMOUS area, some of which were cored adjacent to a fracture zone. I will briefly examine each of these objectives below.

\section{Iceland Geochemical Anomaly}

Basalts from Iceland and the northern part of the Reykjanes Ridge (RER) are geochemically and isotopically distinct from "normal" Mid-Atlantic Ridge (MAR) basalts. Basalts dredged along the RER between Iceland and about $61^{\circ} \mathrm{N}$ show a gradual transition, in terms of their geochemical and isotopic characteristics, between Icelandic (and northern RER) basalts and "normal" MAR basalts (for example: Schilling, 1973; Hart et al., 1973; and Sun et al., 1975). Sites 407,408 , and 409 are on a plate-mantle flow line that intersects the RER along this gradient. Basalts from Sites 407,408 , and 409 should have been formed at the same part of the RER about 38,20 , and 2.2 m.y. ago, respectively (see introduction to this volume).
Basalts dredged from the RER near its intersection with the 407-408-409 flow line have isotopic compositions of $\mathrm{Sr}$ and $\mathrm{Pb}$ similar to those of basalts from Iceland (Hart et al., 1973; Sun et al., 1975). Immediately to the south of this location, RER basalts show a fairly regular decrease in $\mathrm{Sr}^{87} / \mathrm{Sr}^{86}$ ratios (Hart et al., 1973) and $\mathrm{Pb}^{206} / \mathrm{Pb}^{204}$ and $\mathrm{Pb}^{208} / \mathrm{Pb}^{204}$ ratios (Sun et al., 1975). Thus, in terms of $\mathrm{Sr}$ and $\mathrm{Pb}$ isotopic compositions, the area of the RER intersected by the 407-408-409 flow line is the southernmost part of the RER that is now almost totally dominated by the Icelandic influence. If the Iceland "anomaly" was as extensive in the past as it is today, rocks formed at this part of the RER in the past (e.g., basalts from Sites 407 and 408 ) could be similar in $\mathrm{Pb}$-isotopic composition to their modern equivalents. If, on the other hand, the Iceland "anomaly" was less extensive or nonexistent 20 to 38 m.y. ago, $\mathrm{Pb}$ from basalts of Sites 408 and 407 could be less radiogenic than Icelandic, northern RER, and Site 409 basalts; perhaps even in the range of "normal" MAR basalts.

\section{Variations in Layer 2 With Depth}

Another important variation is that of the degree of isotopic homogeneity in Layer 2 of the oceanic crust with depth. The dredge-based studies referred to above relate only to surficial samples. At Site 409 the crew of the Glomar 
Challenger drilled some 239 meters of basalt. This relatively deep penetration provides an opportunity to study possible $\mathrm{Pb}$-isotopic variations with depth at a single site, and to compare data from deep samples with data from earlier dredge haul samples from the same general area.

\section{FAMOUS Area}

The FAMOUS area is geochemically and tectonically somewhat analogous to the area of the RER penetrated at Site 409 and discussed earlier. Like Site 409, the FAMOUS area appears to lie in a transition zone between two distinct geochemical provinces_- "normal" MAR on one hand, and the Azores, an oceanic island province characterized by very radiogenic $\mathrm{Pb}$ (Sun, 1973) and moderately radiogenic $\mathrm{Sr}$ (White et al., 1975) on the other. The Azores may be fed by a mantle plume (Schilling, 1975; White et al., 1976). White and Bryan (1977) show that basalts from the FAMOUS area are in fact intermediate between "normal" MAR basalts and Azores basalts, in terms of their $\mathrm{Sr}^{87} / \mathrm{Sr}^{86}$ ratios and LILelement concentrations. However, $\mathrm{Pb}$ studies by Cumming (1976, 1977) suggest that this mixing hypothesis may be oversimplified. A third component of unusual $\mathrm{Pb}$-isotopic composition may also be involved.

Site 411 is on very young (about $1 \mathrm{~m}$.y.) crust within the median valley of the MAR in the FAMOUS area. Basalts from this site are the youngest yet recovered by DSDP-IPOD. Holes $412 \mathrm{~A}$ and 413 penetrate slightly older crust to the east of the ridge crest, and are on either side of Fracture zone B. Basalts from these two sites may provide clues to the possible effects of a nearby fracture zone on the isotopic character of ridge volcanism.

\section{ANALYTICAL METHODS AND RESULTS}

I received my samples as either very finely pulverized powders or sawn chips. I broke the chips into 1 to $2-\mathrm{mm}$ diameter fragments and washed them for 10 minutes in $2 \mathrm{~N}$ $\mathrm{HCl}$ at room temperature, then 10 minutes at $2 \mathrm{~N} \mathrm{HNO}_{3}$ at room temperature to remove surficial contamination. Acid washing did not seem practical for the very fine powders. I rinsed them three times in distilled acetone prior to digestion. Samples weighing about $100 \mathrm{mg}$ were digested in teflon beakers with a mixture of $\mathrm{HF}$ and $\mathrm{HNO}_{3}, \mathrm{~Pb}$ separated by $\mathrm{HBr}-\mathrm{HCl}$ anion-exchange techniques. The lead was run in the mass spectrometer by the usual silica gel- $\mathrm{H}_{3} \mathrm{PO}_{4}$ method. Blanks for $\mathrm{Pb}$ were about one nanogram.

Precision of the $\mathrm{Pb}$-isotopic analyses at the one-sigma level was normally in the range of 0.1 to 0.2 per cent for $\mathrm{Pb}^{206} / \mathrm{Pb}^{204}$, and was better than 0.1 per cent for $\mathrm{Pb}^{207} / \mathrm{Pb}^{206}$ and $\mathrm{Pb}^{208} / \mathrm{Pb}^{206}$. All ratios have been normalized to "absolute" values via replicate ànalyses of the National Bureau of Standards SRM-981.

The results of the $\mathrm{Pb}$ isotopic analyses are in Table 1 .

\section{DISCUSSION}

\section{RER Transect: Sites 407, 408, 409}

Basalts from Site 409 should be closely comparable to basalts dredged from the RER where it intersects the 407 408-409 flow line (see Sun et al., 1975), and should provide a baseline against which data from Sites 407 and 408 can be compared. Moreover, the deep penetration into igneous
TABLE 1

Pb Isotopic Data for Leg 49 Basalts

\begin{tabular}{|c|c|c|c|c|c|c|}
\hline $\begin{array}{c}\text { Sample } \\
\text { (Interval in } \mathrm{cm} \text { ) }\end{array}$ & $\frac{\mathrm{Pb}^{208} \mathrm{a}}{\mathrm{Pb}^{206}}$ & $\frac{\mathrm{Pb}^{207} \mathrm{a}}{\mathrm{Pb}^{206}}$ & $\frac{\mathrm{Pb}^{204} \mathrm{a}}{\mathrm{Pb}^{206}}$ & $\frac{\mathrm{Pb}^{206} \mathrm{~b}}{\mathrm{~Pb}^{204}}$ & $\frac{\mathrm{Pb}^{207} \mathrm{~b}}{\mathrm{~Pb}^{204}}$ & $\frac{\mathrm{Pb}^{208} \mathrm{~b}}{\mathrm{~Pb}^{204}}$ \\
\hline $407-35-1,35-36$ & 2.0352 & 0.8243 & 0.05305 & 18.85 & 15.54 & 38.36 \\
\hline $407-36-3,63 \cdot 65$ & 2.0415 & 0.8269 & 0.05326 & 18.78 & 15.53 & 38.33 \\
\hline $408-36-4,38-40$ & 2.0340 & 0.8225 & 0.05294 & 18.89 & 15.54 & 38.42 \\
\hline $408-38-4,32-33$ & 2.0497 & 0.8316 & 0.05357 & 18.67 & 15.52 & 38.26 \\
\hline $409-7-6,88-90$ & 2.0556 & 0.8352 & 0.05379 & 18.59 & 15.53 & 38.22 \\
\hline $409-15-1,131-133$ & 2.0469 & 0.8305 & 0.05337 & 18.75 & 15.57 & 38.39 \\
\hline $409-18-1,74-78$ & 2.0552 & 0.8321 & 0.05353 & 18.69 & 15.56 & 38.43 \\
\hline $409-21-1,83-86$ & 2.0475 & 0.8306 & 0.05368 & 18.64 & 15.49 & 38.18 \\
\hline $409-26-1,29-32$ & 2.0550 & 0.8314 & 0.05365 & 18.65 & 15.51 & 38.34 \\
\hline $409-31-1,121-124$ & 2.0488 & 0.8311 & 0.05354 & 18.69 & 15.54 & 38.30 \\
\hline $410-39-5,85-90$ & 2.0185 & 0.7927 & 0.05081 & 19.69 & 15.61 & 39.77 \\
\hline $410 \mathrm{~A}-3-1,75-80$ & 2.0264 & 0.8048 & 0.05156 & 19.40 & 15.61 & 39.30 \\
\hline $410 \mathrm{~A}-5-3,42-45$ & 2.0181 & 0.7985 & 0.05116 & 19.56 & 15.62 & 39.49 \\
\hline $411-3-1,96-100$ & 2.0386 & 0.8270 & 0.05314 & 18.82 & 15.56 & 38.36 \\
\hline $412 \mathrm{~A}-2-2,25-30$ & 2.0384 & 0.8243 & 0.05281 & 18.94 & 15.61 & 38.60 \\
\hline $412 \mathrm{~A}-7-2,110-115$ & 2.0321 & 0.8216 & 0.05279 & 18.94 & 15.56 & 38.49 \\
\hline $413-3-1,35$ & 2.0480 & 0.8268 & 0.05332 & 18.76 & 15.51 & 38.41 \\
\hline
\end{tabular}

aMeasured atomic ratios, normalized to "absolute" values via replicate analyses of NBS SRM-981 Pb standard.

${ }^{b}$ Calculated from the first three columns of data.

basement at Site 409 permits testing of isotopic variability with depth in Layer 2 at this site.

The six analyzed samples of basalt from Site 409 span most of the 239-meter igneous section penetrated at this site. The $\mathrm{Pb}$ isotopic data from these samples are very consistent (Table 1 ). With one exception, the $\mathrm{Pb}^{207} / \mathrm{Pb}^{206}$ ratios agree within \pm 0.1 per cent, the $\mathrm{Pb}^{208} / \mathrm{Pb}^{206}$ ratios within \pm 0.2 per cent, and the $\mathrm{Pb}^{204} / \mathrm{Pb}^{206}$ ratios, which are less precisely determined, within \pm 0.3 per cent. The exception is Sample $409-7-6,88-90 \mathrm{~cm}$, from the uppermost meter or two of basalt in the section. The $\mathrm{Pb}^{207} / \mathrm{Pb}^{206}$ ratio of this sample is almost 0.4 per cent higher than the next highest $\mathrm{Pb}^{207} / \mathrm{Pb}^{206}$ ratio from a Site 409 basalt (Table 1). The $\mathrm{Pb}^{208} / \mathrm{Pb}^{206}$ and $\mathrm{Pb}^{204} / \mathrm{Pb}^{206}$ ratios are also higher than those from the other five Site 409 samples analyzed, but only by statistically insignificant amounts. Whether these isotopic differences represent true primary variations in isotopic composition, alteration effects at or near the basalt/sediment interface, or some other cause, is problematical. I am attempting to resolve this problem through additional experiments. The close agreement of the other five samples from Site 409 does seem to indicate, at least at this site, impressive $\mathrm{Pb}$-isotopic homogeneity with depth in Layer 2 of the oceanic crust.

The Site 409 data are compared with data from basalts dredged along the RER and collected from Iceland (Sun et al. , 1975) in Figure 1. In terms of $\mathrm{Pb}^{206} / \mathrm{Pb}^{204}$ and $\mathrm{Pb}^{208} / \mathrm{Pb}^{204}$ ratios, the Site 409 data are in excellent agreement with the data of Sun et al. (1975) for basalts dredged from the RER near its intersection with the 407-408-409 flow line, and basalts from Iceland itself.

Two samples from Site 408 have somewhat different isotopic compositions (Table 1). Basalt from Core 38 has an isotopic composition indistinguishable from the mean isotopic composition of the Site 409 samples. Basalt from Core 36 , higher in the igneous section, has a slightly higher $\mathrm{Pb}^{206} / \mathrm{Pb}^{204}$ ratio than does basalt from Core 38 or any of the six Site 409 basalts. Whether this higher ratio represents a primary isotopic variation or an alteration effect is problematical. There is only a small difference, however, in Pb isotopic composition between basalt from Core 408-36 and the other Site 408 and Site 409 basalts. All the Site 408 and Site 409 


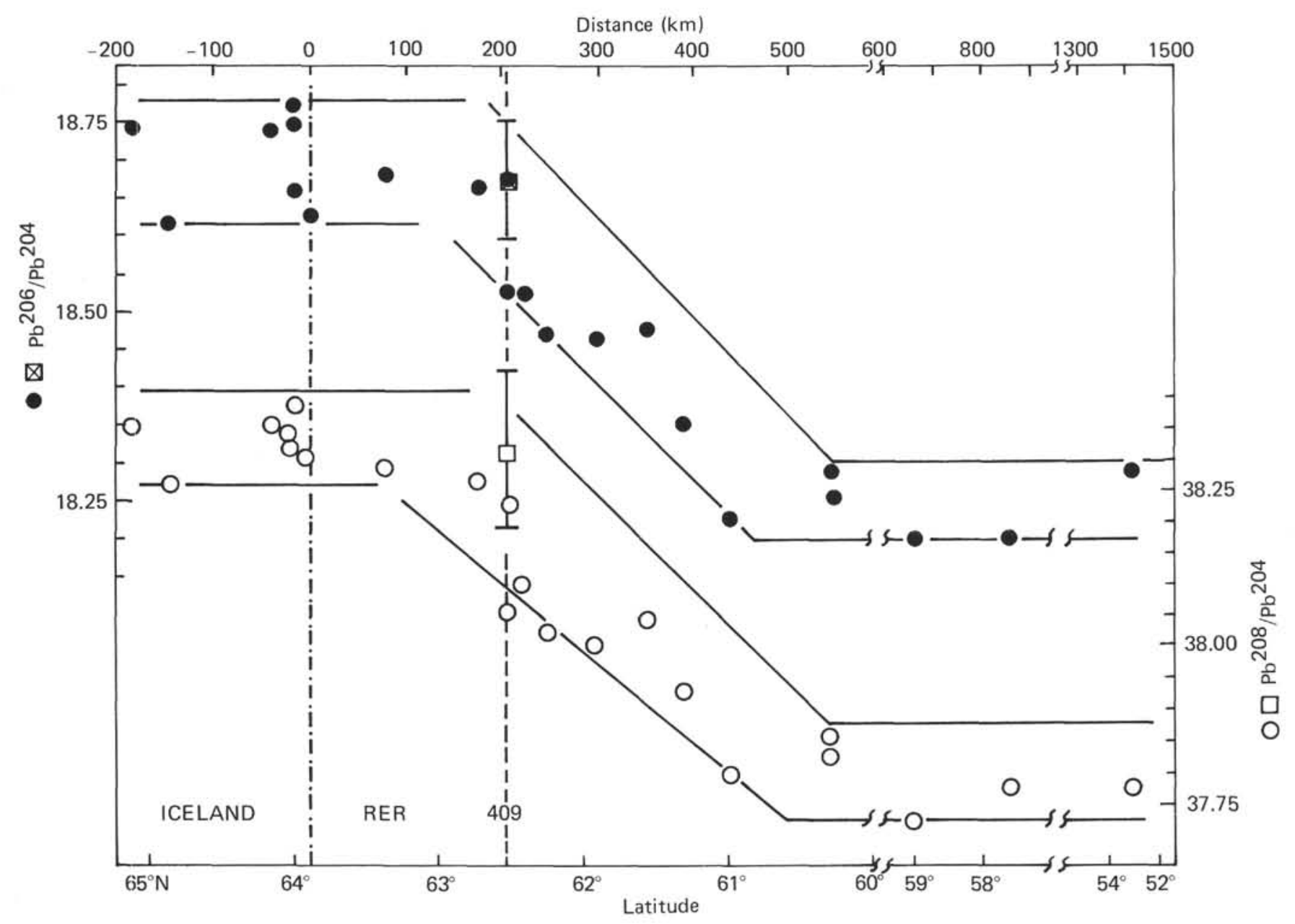

Figure 1. Comparison of $\mathrm{Pb}^{206} / \mathrm{Pb}^{204}$ and $\mathrm{Pb}^{208} / \mathrm{Pb}^{204}$ ratios of Hole 409 basalts with data for basalts from Iceland and the Reykjanes Ridge, modified from fig. 2 of Sun et al. (1975). Data are plotted against distance from Iceland and latitude. Open and closed circles are data from Sun et al. (1975). Open and crossed squares with vertical bars represent the mean and the range of isotopic ratios for six Hole 409 basalts.

samples must be considered isotopically similar to one another and to basalts from Iceland and the northern part of the RER (see Figure 1). This similarity strongly suggests that the influence and extent of the Iceland "anomaly" was as great at the time the Site 408 basalts were erupted (about 20 m.y. ago) as it is today.

I analyzed basalts from Site 407 in order to provide information on the possible existence of the Iceland "anomaly" as long ago as $38 \mathrm{~m} . y$., the age of this site based on the magnetic age of anomaly 13 . The igneous rocks at this site comprise an upper and lower section of basalts separated by a 20 -meter-thick section of sedimentary rocks. From fossils in intercalated sediments, the lower basalts are older than 34 $\mathrm{m} . \mathrm{y}$. The upper basalts appear to be some $6 \mathrm{~m} . \mathrm{y}$. younger than the lower basalts, or about $28 \mathrm{~m}$.y. old, also on the basis of the fossils in intercalated sediments (see 407 site report, this volume). Thus, the upper basalts are probably the result of off-axis volcanism. Both samples (for Cores 35 and 36) are from this upper basalt section. The $\mathrm{Pb}$ isotopic compositions of the two samples are very similar (see Table 1), and fall in the general range of Icelandic basalts, northern RER basalts, and the Site 408 basalts. They are very similar to, but have
$\mathrm{Pb}^{206} / \mathrm{Pb}^{204}$ ratios slightly higher than, the Site 409 basalts. These close similarities are at least suggestive of an Icelandic influence in this area as long ago as $28 \mathrm{~m} . \mathrm{y}$.

\section{Sites 410, 410A}

I analyzed three basalts from Holes 410 and $410 \mathrm{~A}$ for the purpose of obtaining a "normal" MAR basalt isotopic composition to compare against the results from other sites. However, the lead isotopic compositions of the Hole 410 and $410 \mathrm{~A}$ basalts are far more radiogenic than those of any other basalt analyzed in this study (Table 1), or reported by Sun et al. (1975) for Iceland, the RER, or the MAR. Instead, the isotopic compositions of the Hole 410 and Hole $410 \mathrm{~A}$ basalts resemble those reported for volcanic rocks from oceanic islands such as the Canary Islands, the Azores, and Ascension Island (see Sun, 1973). Thus, the Pb isotopic data strongly suggest an off-axis origin for the basalts from Holes 410 and 410A.

Figure 2 is a plot of $\mathrm{Pb}^{207} / \mathrm{Pb}^{204}$ and $\mathrm{Pb}^{208} / \mathrm{Pb}^{204}$ versus $\mathrm{Pb}^{206} / \mathrm{Pb} 204$ for the basalts from Holes 410 and $410 \mathrm{~A}$. The basalts from Sites 407, 408, and 409 and "normal" MAR basalts are also plotted for reference. The highly evolved 


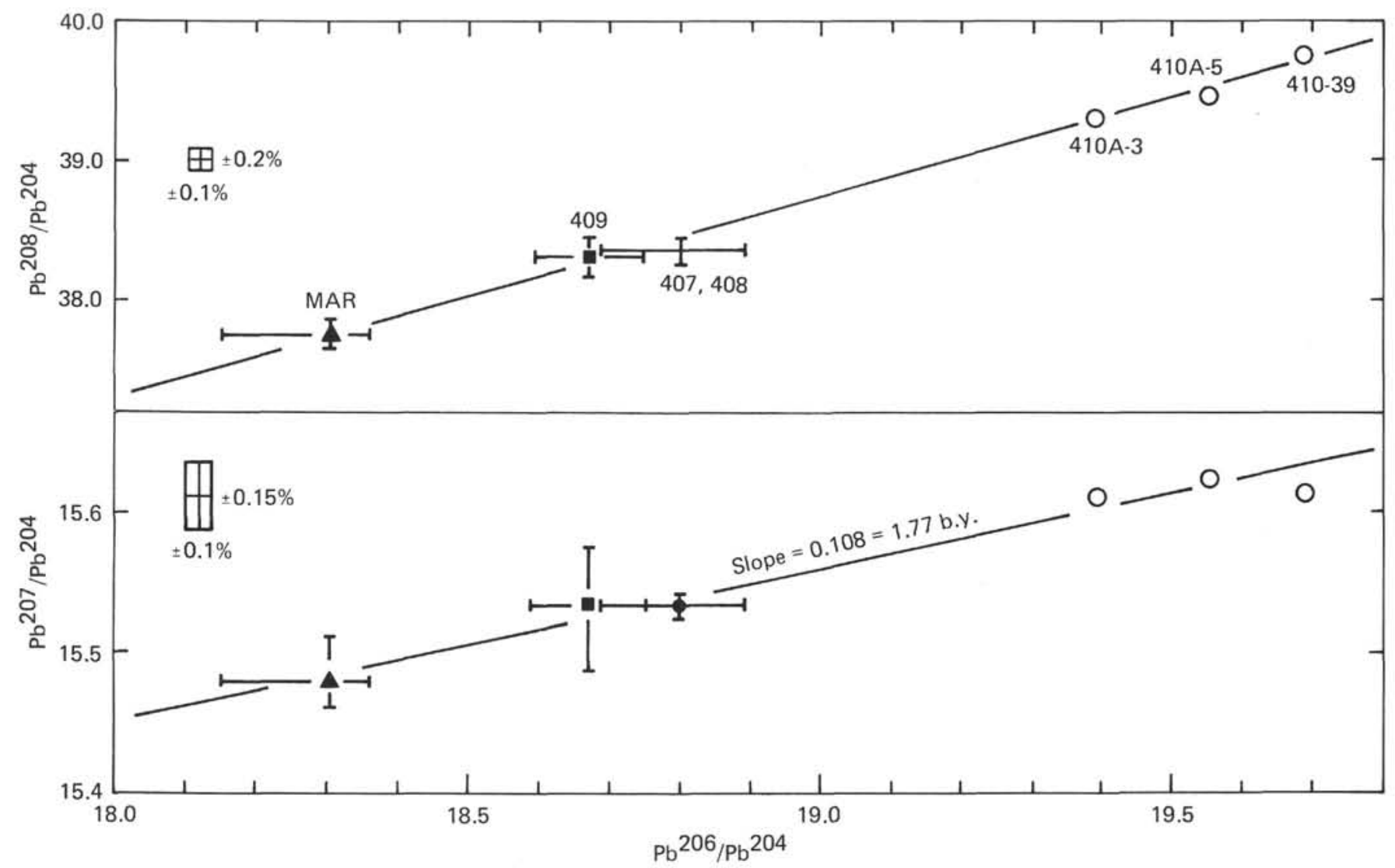

Figure 2. $\mathrm{Pb}^{206} / \mathrm{Pb}^{204}$ vs. $\mathrm{Pb}^{207} / \mathrm{Pb}^{204}$ and $\mathrm{Pb}^{208} / \mathrm{Pb}^{204}$ diagram for basalts from "normal" $\mathrm{MAR}$ (closed triangle, data from Sun, 1973), Holes 407 and 408 (closed circle), Hole 409 (closed square), and Holes 410 and $410 \mathrm{~A}$ (open circles). With the exception of the Hole 410/410A points, the mean values and range of the isotopic ratios are shown by the symbols and bars, respectively. Rectanges on left side of diagram indicate uncertainties of \pm 0.1 per cent in the $P b^{206} / P^{204}$ ratio, \pm 0.15 per cent in the $\mathrm{Pb}^{207} / \mathrm{Pb}^{204}$ ratio, and \pm 0.20 per cent in the $\mathrm{Pb}^{208} / \mathrm{Pb}^{204}$ ratio.

nature of the Hole 410/410A samples, relative to MAR and Site 407, 408, and 409 basalts, is obvious. Evidently, the Hole 410/410A basalts have been derived from a relatively undepleted source - one characterized by a high $\mathrm{U}^{238} / \mathrm{Pb}^{204}$ ratio $(\mu)$ for a substantial time interval. I can estimate this time interval by assuming that the source regions of the plotted basalts have a simple two-stage history of $\mathrm{U}-\mathrm{Pb}$ evolution (i.e., that the source regions all differentiated at time $\mathrm{T}$ from an originally homogeneous reservoir). All the data, within the limits of uncertainty, do in fact fall on a single, hand-fitted line in the $\mathrm{Pb}^{207} / \mathrm{Pb}^{204}$ versus $\mathrm{Pb}^{206} / \mathrm{Pb}^{204}$ plot (Figure 2). Assuming that this line is a secondary isochron in a simple two-stage model of $\mathrm{Pb}$ evolution, I calculate an "age" or time of major differentiation of the source regions of these basalts of 1.77 b.y. This "age" is subject to a much more precise secondary isochron age of 1.80 b.y. reported for the Canary Islands by Sun (1973). This agreement supports the idea, proposed by a number of authors, of a widespread mantle differentiation event at about this time (for recent discussions, see Church and Tatsumoto, 1975, and Brooks et al., 1976).

On the plot of $\mathrm{Pb}^{208} / \mathrm{Pb}^{204}$ versus $\mathrm{Pb}^{206} / \mathrm{Pb}^{204}$, the data also fit a single line rather well (Figure 2). In this plot the slope is much steeper than that reported by Sun (1973) for the Canary Islands: 1.42 versus 0.94 , respectively. I should note that the slope in Figure 2 is controlled strongly by the inclusion of the MAR basalt data. The Hole 410/410A data alone would still define (less precisely) a similar line, however. Thus, the source region of the Hole 410/410A basalts has had a greater time-integrated $\mathrm{Th} / \mathrm{U}$ ratio than has the source region of the Canary Island volcanic rocks.

An alternative explanation is that the linear relationships in Figure 2 represent mixing lines. According to this hypothesis, the Site 407,408 , and 409 basalts represent mixtures of a more primitive or depleted end-member ("normal" MAR source material) and a more evolved or undepleted end-member (if not Hole 410/410A-like material, then at least something that would fall along the same regression line). I refer the reader to studies by Schilling (1973), Hart et al. (1973), and Sun et al. (1975) for more details on mixing models as applied to Iceland and the Reykjanes Ridge.

\section{FAMOUS Area}

$\mathrm{Pb}$-isotopic data from basalts from Holes 411, 412A, and 413 are shown in Figure 3, along with data from Leg 37 FAMOUS sites (Cumming, 1976, 1977); the Azores (Sun, 1973); and "normal"' MAR basalts (Sun, 1973). The FAMOUS area $\mathrm{Pb}$ results clearly do not support the idea that 


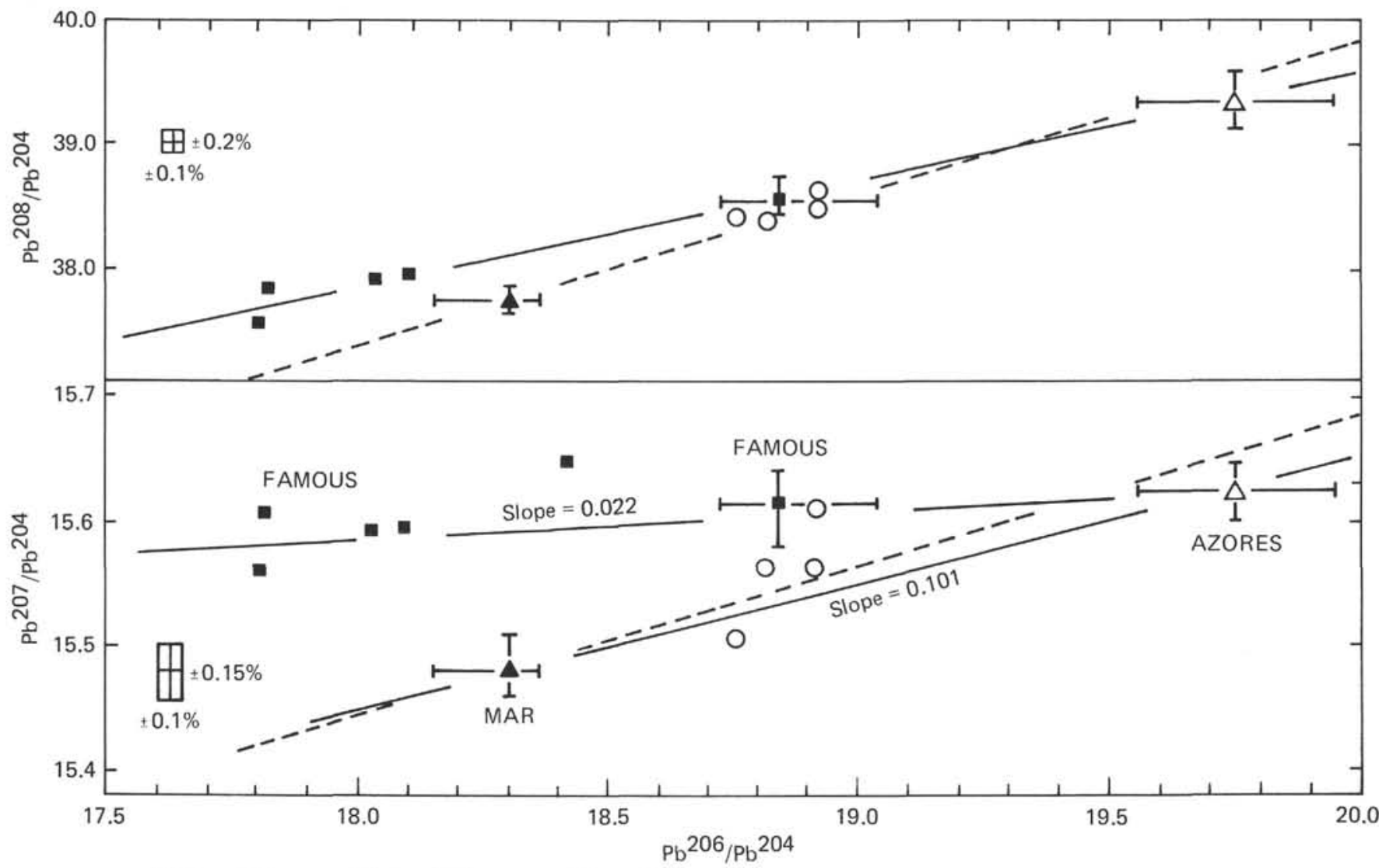

Figure 3. $\mathrm{Pb}^{206} / \mathrm{Pb}^{204}$ vs. $\mathrm{Pb}^{207} / \mathrm{Pb}^{204}$ and $\mathrm{Pb}^{208} / \mathrm{Pb}^{204}$ diagram for basalts from "normal" $M A R$ (closed triangle, data from Sun, 1973), volcanic rocks from the Azores (open triangle, data from Sun, 1973), Leg 37 FAMOUS area basalts (closed squares, data from Cumming, 1976, 1977), and Leg 49 FAMOUS area basalts (open circles). The mean values and ranges of MAR, Azores, and some of the FAMOUS data are shown by the symbols and bars. Hand-fitted solid lines for possible Leg 37-Azores and MAR-Azores mixing lines are shown in the diagram, along with a dashed line representing the Hole $410 / 410 A-M A R$ line (Figure 2) for reference (the MAR-Azores line has been omitted from the $P b^{206} / P^{204} v s . P b^{208}$ / $\mathrm{Pb}^{204}$ diagram for clarity.

FAMOUS basalts can be considered transitional between two simple end-members (MAR and the Azores), as suggested by White and Bryan (1977). Basalts from Hole 411, Core 412A-7, and Hole 413 are compatible with the above idea. They fit a mixing line (or a secondary isochron of about 1.6 b.y.) between MAR basalts and Azores volcanic rocks (lower solid line in the $\mathrm{Pb}^{207} / \mathrm{Pb}^{204}$ vs. $\mathrm{Pb}^{206} / \mathrm{Pb}^{204}$ diagram, Figure 3), within the limits of error. However, $\mathrm{Pb}$ data from Core 412A-2 and the Leg 37 Holes 332A, 332B, and 335 (Cumming, 1976, 1977) require a third end-member, one with a high $\mathrm{Pb}^{207} / \mathrm{Pb}^{204}$ ratio relative to its $\mathrm{Pb}^{206} / \mathrm{Pb}^{204}$ ratio. Section 332B-42-2 (Cumming, 1976, 1977) has the lowest $\mathrm{Pb}^{206} / \mathrm{Pb}^{204}$ ratio (about 17.8) reported for the FAMOUS area, an exceptionally high $\mathrm{Pb}$ concentration $(20.5 \mathrm{ppm})$, and thus may be representative of the $\mathrm{Pb}$ isotopic composition of this end-member. The low slope of the line between this end-member and the Azores ( 0.22 , upper solid line in the $\mathrm{Pb}^{207} / \mathrm{Pb}^{204}$ vs. $\mathrm{Pb}^{206} / \mathrm{Pb}^{204}$ diagram, Figure 3) rules out the possibility of the line being any kind of an isochron. The FAMOUS samples that lie along the line probably result from mixing processes. Basalts from Site 411 and Core 412A-7 have isotopic compositions that tend to lie between the MAR-Azores and FAMOUS-Azores lines. These basalts may represent mixtures of all three end-members. Additional $\mathrm{Pb}$ isotopic measurements would be most helpful in deciphering the origins of the FAMOUS basalts.

The $\mathrm{Pb}^{207} / \mathrm{Pb}^{204}$ ratio of basalt from Site 413 is significantly lower than that of any other FAMOUS basalt (Table 1). It may be significant that Site 413 is the only site on the south side of fracture zone B. All the other sites are north of fracture zone $\mathrm{B}$, in the crustal block between fracture zones A and B. Possibly the fracture zone exerts a real influence on the geochemistry of basalts erupted on either side of it. However, much additional work will be needed to prove that the isotopic differences across the fracture zone are outside the range of variability within a single crustal block in this isotopically complex area.

\section{SUMMARY}

$\mathrm{Pb}$ isotopic data for Leg 49 basalts suggest the following main conclusions:

1) Basalts from Site 409 are isotopically quite homogeneous throughout a 239-meter section, and are isotopically indistinguishable from basalts from Iceland and the northern RER.

2) Basalts from Site 408 and the upper volcanic section of 
Site 407 are also quite similar-in terms of $\mathrm{Pb}$ isotopic compositions - to Icelandic and northern RER basalts; this suggests the presence of an Icelandic influence at this latitude 20 , and perhaps about $28 \mathrm{~m}$.y. ago.

3) Basalts from Holes 410 and $410 \mathrm{~A}$ contain highly radiogenic lead similar to that reported from oceanic islands, and are evidently the products of off-ridge volcanism fed by a relatively undepleted mantle source. The data lend support to the idea of a major mantle differentiation event about $1.8 \mathrm{~b} . \mathrm{y}$. ago.

4) Basalts from the FAMOUS area (Holes 411, 412A, 413) have isotopic compositions of $\mathrm{Pb}$ that are compatible with a three-component mixing model. End-members could include "normal" MAR source material, Azores source material, and a high $\mathrm{Pb}^{207} / \mathrm{Pb}^{204}$-low $\mathrm{Pb}^{206} / \mathrm{Pb}^{204}$ source material. A single sample south of fracture zone B is isotopically distinct from samples north of fracture zone B. Possibly the fracture zone is a controlling influence.

\section{ACKNOWLEDGMENTS}

Reviewed by Drs. G. R. Tilton, S. E. Church, and R. Hurst.

\section{REFERENCES}

Brooks, C., James, E. E., Hart, S. R., and Hofmann, A. W., 1976. Rb-Sr mantle isochrons, Carnegie Institution of Washington Yearbook 75, p. 176-207.

Church, S. E. and Tatsumoto, M., 1975. Lead isotope relations in ocean ridge basalts from the Juan de Fuca-Gorda ridge area, northeast Pacific Ocean, Contributions to Mineralogy and Petrology, v. 53, p. 253-279.

Cumming, G. L., 1976. Lead isotope ratios in DSDP Leg 37 basalts, Earth and Planetary Science Letters, v. 31, p. 179. , 1977. Lead and uranium in basalts from DSDP Leg 37 cores, Canadian Journal of Earth Sciences, v. 14, p. 768.

Hart, S. R., Schilling, J.-G., and Powell, J. L., 1973. Basalts from Iceland and along the Reykjanes Ridge: $\mathrm{Sr}$ isotope geochemistry, Nature, v. 246, p. 104.

Schilling, J.-G.,1973. Iceland mantle plume: geochemical study of the Reykjanes Ridge, Nature, v. 242, p. 565.

1975. Azores mantle blob: rare earth evidence, Earth and Planetary Science Letters, v. 25, p. 103.

Sun,S.-S., 1973. Lead isotope studies of young volcanic rocks from oceanic islands, mid-ocean ridges, and island arcs, Columbia University, New York, unpublished Ph.D. dissertation.

Sun, S.-S., Tatsumoto, M., and Schilling, J. G., 1975. Mantle plume mixing along the Reykjanes Ridge axis: lead isotopic evidence, Science, v. 190, p. 143.

White, W. M., Hart, S. R., and Schilling, J.-G., 1975. Geochemistry of the Azores and the Mid-Atlantic Ridge: $29^{\circ} \mathrm{N}$ to $60^{\circ} \mathrm{N}$, Carnegie Institution of Washington Yearbook 74, p. 224.

White, W. M., Schilling, J.-G., and Hart, S. R., 1976. Evidence for the Azores mantle plume from strontium isotope geochemistry of the central North Atlantic, Nature, v. 263, p. 659 .

White, W. M., and Bryan, W. B., 1977. Sr-isotope, K, Rb, Cs, Sr, $\mathrm{Ba}$, and rare-earth geochemistry of basalts from the FAMOUS area, Geological Society of America Bulletin, v. 88, p. 571. 